\title{
OURO SECUNDÁRIO EM COURAÇAS LATERÍTICAS NA REGIÃO DE CUIABÁ - MT
}

\author{
S.M.B.de Oliveira ${ }^{1}$ \\ E.G.Campos ${ }^{2}$
}

No Estado do Mato Grosso ocorre uma espessa seqüência de idade proterozóica - Grupo Cuiabá - composta de rochas metassedimentares orientadas na direção NE a EW e cortadas por abundantes veios de quartzo. Essa seqüência consiste de rochas de baixo grau: metaconglomerados, metarenitos, filitos e calcários, principalmente. Os veios de quartzo pertencem a pelo menos duas gerações distintas, a mais antiga concordante com a direção regional e a mais nova de direção NW (PIRES et al., 1986). Ambas podem ser portadoras de ouro, que ocorre associado sobretudo à pirita, mas também à galena, arsenopirita e calcopirita.

O clima na região é tropical úmido com no máximo quatro meses secos por ano (maio a agosto), período em que a precipitação não excede $100 \mathrm{~mm}$. Nas proximidades da cidade de Cuiabá, a temperatura média anual é de $25,6^{\circ} \mathrm{C}$ e a precipitação média anual de 1378 $\mathrm{mm}$.

$\mathrm{Na}$ área estudada, a paisagem consiste uma extensa superfície aplainada, ligeiramente ondulada a altitudes de cerca de $200 \mathrm{~m}$ (Baixada Cuiabana), drenada pelo rio Cuiabá, que pertence à bacia do Paraguai. Um perfil de alteração laterítico capeado por couraça cobre essa superfície. A couraça é geralmente estéril, mas pode conter pepitas de ouro quando desenvolvida sobre mineralização primária desse elemento.

Um estudo detalhado do perfil de alteração foi efetuado no garimpo de Casa de Pedra, a $30 \mathrm{~km}$ a leste de Cuiabá. Da base para o topo do perfil podem ser reconhecidos os seguintes horizontes:

\footnotetext{
Departamento de Geologia Geral, Instituto de Geociências/USP, São Paulo. ${ }^{2}$ Pós-graduação, Instituto de Geociências/USP, São Paulo.
} 
- Rocha alterada (espessura?) - Filito cinza a marrom com xistosidade bem preservada, composto de quartzo, sericita, clorita, caulinita e goethita, contendo zonas com acumulações ferruginosas locais devido à oxidação de sulfetos. Os veios de quartzo que o cortam, embora fragmentados, permanecem em seus lugares originais.

- Argila mosqueada (1,2m de espessura) - Os níveis inferiores deste horizonte são formados por um plasma argiloso amarelo (caulinita, quartzo e sericita), onde se distribuem manchas avermelhadas (goethita, caulinita e quartzo) que se tornam cada vez mais abundantes e endurecidas em direção ao topo. A estrutura original da rocha, preservada na base desse horizonte, tende a desaparecer para cima. Os veios de quartzo se desagregam e se misturam com os materiais lateríticos.

- Couraça (1m de espessura) - Consiste essencialmente de nódulos derivados das manchas do horizonte subjacente (goethita, hematita e quartzo) e de fragmentos angulosos de quartzo derivados da desagregação dos veios, firmemente cimentados por uma matriz argilosa amarela (caulinita, quartzo e gibbsita). A couraça é recoberta por um horizonte nodular formada por seus próprios fragmentos envolvidos em um cortex goethítico.

Evidências texturais e petrográficas indicam uma origem autóctone para o perfil, através da laterização dos filitos sob condições climáticas possivelmente mais secas. Atualmente, a tendência parece ser em direção ao desmantelamento da couraça e não à sua formação. Perfis lateríticos providos de couraça foram descritos na África por vários autores, entre os quais LEPRUN (1979), AMBROSI \& NAHON (1986) e FREYSSINET et al. (1987), por exemplo.

A mineralização aurífera está intimamente associada aos veios de quartzo nos níveis inferiores do perfil de alteração, tornando-se mais espalhada nos níveis superiores, à medida que a desagregação dos veios avança.

Nos veios, o ouro ocorre em drusas de quartzo milimétricas como pequenos cristais euédricos $(<100 \mu \mathrm{m}$ ), ou preenchendo fraturas nos cristais de quartzo. De forma semelhante ao depósito de Fazenda Brasileiro (VASCONCELLOS, 1987), o ouro também ocorre na superfície dos sulfetos, em grãos de forma irregular, geralmente com dimensão inferior a $1 \mathrm{~mm}$. Ao microscópio, os grãos maiores aparecem relacionados às zonas mais oxidadas dos sulfetos. Nos concentrados de bateia, os grãos de ouro associados a quartzo e sulfetos mostram figuras de corrosão, como fendas de dissolução e cavidades na superfície. Esses grãos apresentam pureza variável entre 950 e 970, com 3 a 5\% de $\mathrm{Ag}$. Cobre e ferro foram pesquisados e não foram detectados. Além do ouro, os concentrados de bateia contêm magnetita, zircão, turmalina, rutilo e monazita. 
No concentrados obtidos da couraça e do horizonte nodular que a recobre, aparecem pepitas de ouro de dimensâo milimétrica. Como em outras ocorrências de ouro laterítico (FREYSSINET et al., 1987; VASCONCELLOS, 1987; CARVALHO, 1984; WILSON, 1984), nas pepitas há uma estreita associação entre o ouro e o plasma ferruginoso. Nos bolsões de plasma ferruginoso predominantemente goethítico incluídos nas pepitas, encontra-se uma grande quantidade de finíssimas partículas de ouro $(1-40 \mu \mathrm{m})$ de forma irregular e distribuição aleatória, ou alongadas com orientação paralela. O contato entre os bolsões ferruginosos e o ouro é brusco, sendo as zonas marginais dos bolsões mais ricas em hematita e desprovidas de partículas de ouro. $\mathrm{O}$ ouro das pepitas apresenta pureza maior que 990, sendo as partículas disseminadas nos bolsões mais puras ainda, com menos de $0,1 \% \mathrm{Ag}$.

Como conclusão, pode-se dizer que o ouro sofreu uma evolução relacionada com a evolução do perfil laterítico. Na rocha alterada e na argila mosqueada, onde ele está associado ao quartzo e a sulfetos mais ou menos oxidados, ocorreu dissolução, demonstrada pelas figuras de corrosão na superfície das partículas. A formação de ouro secundário nos níveis superiores do perfil é demonstrada pelo tamanho maior das partículas, sua maior pureza e intercrescimento entre o ouro e os b́xidos e hidróxidos de ferro neoformados.

\section{REFERÊNCIAS BIBLIOGRÁFICAS}

AMBROSI, J.P. \& NAHON, D. (1986) Petrological and geochemical differentiation of lateritic iron crust profiles. Chemical Geology, 57:371-393.

CARVALHO, I.G. (1984) Mineralizações auríferas de Gentio do Ouro (Bahia): características micromorfologicas. In: CONGRESSO BRASILEIRO DE GEOLOGIA, 33, Rio de Janeiro, 1984. Anais. Rio de Janeiro, SBG. V.8, p.4024-4031.

FREYSSINET, P.; ZEEGERS, H.; TARDY, Y. (1987) Néoformation d'or dans les cuirasses latéritiques: dissolution, migration, précipitation. Comptes Rendus de l'Academie des Sciences Paris, 305(2):867-874.

LEPRUN, J.C. (1979) Les cuirasses ferrugineuses des pays cristallins de l'Afrique occidentale sèche. Genèse. transformations. dégradations. Sciences Géologiques Mémoir, 58:1-224. 
PIRES, F.R.M.; GONÇALVES, F.T.T.; RIBEIRO, L.A.S.; SIQUEIRA, A.J.B. (1986) Controle das mineralizações auríferas do Grupo Cuiabá, MT. In: CONGRESSO BRASILEIRO DE GEOLOGIA, 34, Goiânia. Anais. Goiânia, SBG. V.5, p.2383-2396.

VASCONCELLOS, P.M.de P. (1987) Gold geochemistry in a semi-arid weathering environment: a case study of the Fazenda Brasileiro deposit, Bahia-Brazil. Austin, 254p. (Master Thesis - University of Texas).

WILSON, A.F. (1984) Origin of quartz-free nuggets and supergene gold in laterites and soils - a review and some new observations. Australian Journal of Earth Sciences, 31:303-316. 